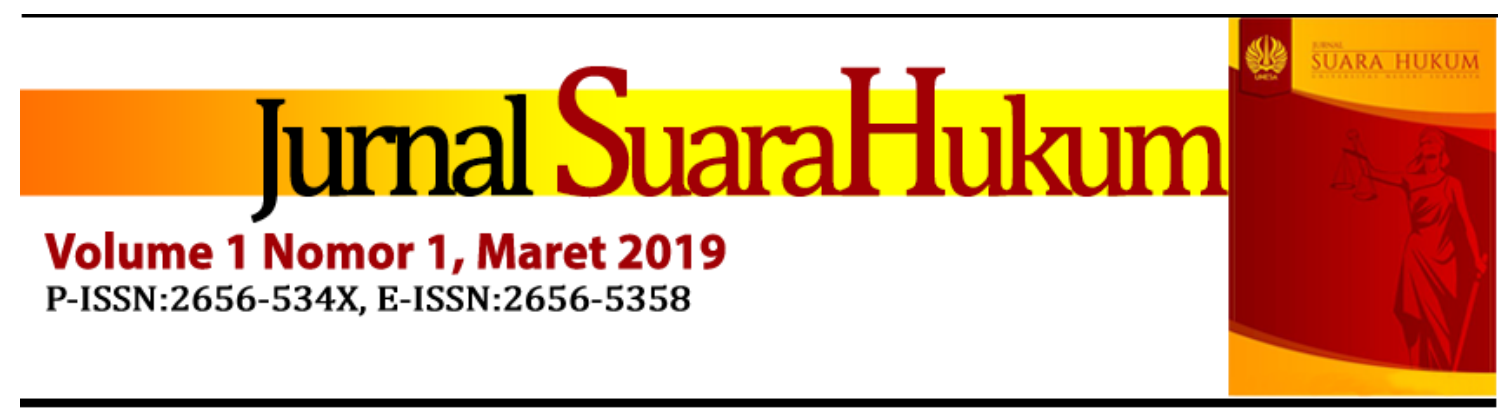

\title{
Harmonisasi Perlindungan Harta Kekayaan Anak dalam Perwalian melalui Penguatan Peran Wali Pengawas
}

\author{
Yulita Dwi Pratiwi ${ }^{1}$
}

Balai Harta Peninggalan Surabaya, Surabaya, Indonesia. yulita95dp@gmail.com

\begin{abstract}
Guardianship is the supervision of children who are no longer under the authority of their parents, and the management of objects or property of the children carried out by the guardian. In carrying out their duties, the guardian is supervised by the guardian supervisor, which based on Article 366 Indonesian Civil Code, the authority is given to the Weskamer. This office is one of the technical implementation units under the Ministry of Law and Human Rights. However, the supervision process can hardly be carried out by the Weskamer $r_{L}$ that relates to its role that requires synergy with the role of other institutions. It shows that there is disharmony in the implementation of protection of children's assets in guardianship, which eliminates the element of supervision by the state through the Weskamer. Therefore, an idea is needed in harmonizing the protection of children's assets in guardianship through strengthening the role of guardian. This research uses normative method which is a part of legal research. Normative legal research aims to find solutions to juridical problems that arise from legal issues and provide prescriptions on these legal issues. Based on the results of the study, systematic and concrete steps are needed to improve the rules by harmonizing laws as well as institutions regarding the protection of the assets of the children by strengthening the role of guardian supervisor.
\end{abstract}

Keywords: harmonization, guardianship, guardian supervisor, weskamer.

\section{Pendahuluan}

Kedudukan anak sebagai generasi muda yang akan meneruskan cita-cita luhur bangsa, calon-calon pemimpin bangsa di masa mendatang dan sebagai sumber harapan bagi generasi terdahulu, perlu mendapat kesempatan seluasluasnya untuk tumbuh dan berkembang dengan wajar baik secara rohani, jasmani, dan sosial. Perlindungan anak merupakan usaha dan kegiatan seluruh lapisan masyarakat dalam berbagai kedudukan dan peranan, yang menyadari pentingnya anak bagi nusa dan bangsa di kemudian hari. Jika mereka telah 
matang pertumbuhan fisik maupun mental dan sosialnya, maka tiba saatnya menggantikan generasi terdahulu. ${ }^{1}$

Kegiatan perlindungan anak membawa akibat hukum, baik dalam kaitannya dengan hukum tertulis maupun tidak tertulis. Hukum merupakan jaminan bagi kegiatan perlindungan anak. Arif Gosita mengemukakan bahwa kepastian hukum perlu diusahakan demi kelangsungan kegiatan perlindungan anak dan mencegah penyelewangan yang membawa akibat negatif yang tidak diinginkan dalam pelaksanaan perlindungan anak. ${ }^{2}$ Perlindungan anak dapat dibedakan dalam dua bagian yaitu: ${ }^{3}$

a. Perlindungan anak yang bersifat yuridis, yang meliputi: perlindungan dalam bidang hukum publik dan dalam bidang hukum keperdataan;

b. Perlindungan anak yang bersifat non yuridis, meliputi: perlindungan dalam bidang sosial, bidang kesehatan, bidang pendidikan.

Salah satu contoh konkret perlindungan anak yang bersifat yuridis dalam bidang keperdataan adalah dalam lingkup perwalian. Hukum di Indonesia mendefinisikan perwalian sebagai kewenangan dalam melakukan perbuatan hukum tertentu demi kepentingan dan hak anak yang orang tua kandungnya telah meninggal dunia atau juga diartikan suatu perlindungan hukum yang diberikan pada seorang anak yang belum dewasa atau belum pernah kawin yang tidak dibawah kekuasaan kedua orang tua. ${ }^{4}$

Wali dalam menjalankan tugasnya diwajibkan untuk memelihara anak tersebut yang berada di bawah perwaliannya dan juga mengurus harta benda anak itu dengan sebaik mungkin dengan cara menghormati agama dan kepercayaan anak tersebut. Selain itu, wali wajib memelihara semua harta benda si anak pada saat memulai jabatannya sebagai seorang wali dan juga wajib mencatat semua perubahan yang ada dari harta benda anak itu. ${ }^{5}$ Wali yang ditunjuk berdasarkan Penetapan Pengadilan dapat mewakili anak untuk melakukan perbuatan hukum, baik di dalam maupun di luar pengadilan untuk kepentingan terbaik bagi si anak seperti tercantum dalam Pasal 33 dan 34 UU No. 23 Tahun 2002 tentang Perlindungan Anak. Ayat (2) dan (3) juga mengatur bahwa wali memiliki kewajiban mengelola harta benda milik anak tersebut untuk kepentingan si anak.

\footnotetext{
${ }^{1}$ Maidin Gultom. (2003). Perlindungan Hukum Terhadap Anak dalam Sistem Peradilan Pidana Anak di Indonesia. Bandung: Refika Aditama, hal. 33

2 Arif Gosita dalam Maidin Gultom. (2003). Perlindungan Hukum Terhadap Anak Dalam Sistem Peradilan Pidana Anak di Indonesia. Bandung: Refika Aditama, hal. 33

3 Ibid, hal. 34.

4 Wahyono Darmabrata dan Surini Ahlan Sjarif. (2004). Hukum Perkawinan dan Keluarga di Indonesia. Jakarta: Fakultas Hukum Universitas Indonesia, hal. 147

5 Indonesia, Undang-Undang Nomor 1 Tahun 1974 tentang Perkawinan, Lembaran Negara Republik Indonesia Tahun 1974 Nomor 1, Pasal 151 ayat (2-5).
} 
Wali dalam menjalankan perannya tidak terlepas dari pengawasan wali pengawas. Pasal 366 Kitab Undang-Undang Hukum Perdata (selanjutnya disebut KUHPerdata) menyebutkan bahwa “Dalam tiap-tiap perwalian yang diperintahkan di Indonesia, Balai Harta Peninggalan berwajib melakukan tugas selaku wali pengawas". Balai Harta Peninggalan (selanjutnya disebut BHP) sebagai wali pengawas memiliki kewajiban sebagai pihak mewakili kepentingan anak yang belum dewasa, apabila ada kepentingan anak yang bertentangan dengan kepentingan si wali, dengan tidak mengurangi kewajiban-kewajiban yang teristimewa maka pengawasan ini dibebankan kepada BHP dalam hal perwalian pengawas itu diperintahkan kepadanya.

Wali pengawas wajib memaksakan kepada wali atas ancaman kerugian dan bunga dimana wali diberikan hukuman mengganti biaya, dan membuat inventaris atau perincian barang-barang harta peninggalan dalam segala warisan yang jatuh kepada si anak yang belum dewasa. Namun, pada proses pengawasan perwalian menjadi disharmoni manakala proses perwalian tersebut dianggap telah selesai oleh wali setelah adanya penetapan pengadilan. Wali sering melalaikan ketentuan Pasal 368 KUHPerdata, yang mewajibkan wali untuk melakukan pemberitahuan kepada BHP tentang terjadinya. Hal tersebut mengingat amar penetapan perwalian oleh Pengadilan Negeri yang minim mencantumkan kewajiban wali untuk melaporkan kepada BHP selaku wali pengawas.

Pemberitahuan tersebut bukan proses jangka pendek yang menggugurkan kewajiban wali untuk melaporkan kepada wali pengawas, namun terdapat prosedur lain yang wajib dilakukan oleh wali dan wali pengawas dalam menjamin kepentingan yang terbaik bagi anak. Prosedur tersebut mulai dari pengambilan sumpah, pencatatan dan inventarisir harta kekayaan anak, mengawasi seluruh perbuatan hukum yang dilakukan wali atas nama anak, meminta wali membuat pertanggungjawaban berkala dan pertanggungjawaban setelah perwalian tersebut berakhir.6 Sebagai contoh data klasifikasi perkara permohonan wali dan izin jual pada sistem informasi penelusuran perkara Pengadilan Negeri Surabaya tahun 2018, menunjukkan bahwa 170 permohonan wali dan izin jual dalam status perkara minutasi.7 Jika sesuai dengan ketentuan yang diatur dalam Pasal 368 KUHPerdata, dalam hal ini BHP Surabaya yang

\footnotetext{
${ }^{6}$ Lihat ketentuan perwalian dalam Kitab Undang-Undang Hukum Perdata.

7 Sistem Informasi Penelusuran Perkara Pengadilan Negeri Surabaya. (2019). Tersedia online di http:/ / sipp.pn-

surabayakota.go.id/list_perkara/page/1/SXYwTGR3b3VMc2FISi9CeHV0YXZjblBSdTdraG1LRFV6d3hB dFZtbWw5MjRwYkNva0M2bzIrR21YdDREUDVDQTJLcDVZR3JUNUwxZDIMeHBUdDI5M1E9PQ==/W G5LZDh1SE5IS0VuVHFER3o2dzd2REsrU1V4WTJNb3R2TC9BVGg3cWNwM3JSNj1CcUtxbStGTHgzMUR wQk8xZ1g3NTB5MlVPSkk1YldOc0hkYko5Q2c9PQ==/col/2, [diakses pada 10 Februari, 2019]
} 
memiliki kompetensi relatif di mana permohonan perwalian dan penetapan izin jual ditetapkan, maka seharusnya BHP Surabaya telah menerima salinan penetapan maupun pemberitahuan oleh wali berkaitan dengan proses pengawasan wali. Namun, pada tahun 2018 BHP Surabaya tidak menerima salinan penetapan maupun pemberitahun terjadinya perwalian yang terjadi di Surabaya. ${ }^{8}$

Harta kekayaan anak dapat saja dialihkan oleh wali melalui jual beli, sewamenyewa, maupun perbuatan hukum lainnya di mana hal tersebut tidak diperkenankan dalam Pasal 393 KUHPerdata, kecuali mendapat izin dari hakim. ${ }^{9}$ Penetapan izin dari hakim selama ini tidak melibatkan peran BHP selaku wali pengawas, yang dalam proses perwalian diperintahkan oleh undangundang untuk turut campur dalam seluruh tindakan yang dilakukan wali atas nama anak. Di sisi lain, dalam terjadinya proses peralihan, pemisahan dan pembagian hak anak yang melibatkan notaris dan PPAT, juga tidak melibatkan peran wali pengawas. Proses peralihan, pemisahan dan pembagian hak tersebut dilakukan hanya berdasarkan pemenuhan syarat formal yakni adanya penetapan perwalian dan/atau izin jual dan memberikan peluang untuk menjual harta anak di bawah umur tanpa pengawasan BHP. ${ }^{10}$

Pengawasan terhadap perwalian ini memiliki urgensi tersendiri agar harta dari anak yang di bawah perwalian tidak disalahgunakan oleh wali dan sebagai langkah preventif adanya sengketa waris. Gagasan untuk memperbarui adanya disharmoni pelaksanaan perlindungan terhadap harta kekayaan anak dalam perwalian, yang dalam hal ini kepentingan dan perbuatan hukum anak diwakili oleh wali tidak diharapkan menghilangkan salah satu peran dari pengawasan oleh negara melalui BHP. Di mana hal tersebut bertujuan melindungi pengelolaan harta kekayaan yang menjadi hak anak dipergunakan untuk kepentingan terbaik bagi anak dan dapat dipertanggungjawabkan ketika anak tersebut dewasa. Dalam menuju tata pemerintahan yang baik, harmonisasi hukum harus dapat mencerminkan keterpaduan dalam penerapan peraturan perundang-undangan, yang terdiri atas mekanisme pengaturan, administrasi pengaturan, antisipasi terhadap perubahan dan penegakan hukum dan sebaliknya dalam keterpaduan tersebut tercermin harmonisasi hukum ${ }^{11}$. Berdasarkan hal tersebut maka perlu sebuah kajian bagaimana harmonisasi

\footnotetext{
${ }^{8}$ Buku Register Perwalian Balai Harta Peninggalan Surabaya.

9 Lihat Pasal 393 KUHPerdata

10 Siti Hafsah Ramahdhan. (2004). “Tanggungjawab Balai Harta Peninggalan Selaku Wali Pengawas Terhadap Harta Anak di Bawah Umur (Studi Mengenai Eksistensi Balai Harta Peninggalan Medan Sebagai Wali Pengawas)", Tesis, Universitas Sumatera Utara, hal. 74

${ }^{11}$ Kusnu Goesniadhie. (2010). Harmonisasi Sistem Hukum Mewujudkan Tata Pemerintahan yang Baik. Malang: Nasa Media, hal. 12
} 
perlindungan harta kekayaan anak dalam perwalian melalui penguatan peran wali pengawas.

\section{Metode Penelitian}

Penulisan ini menggunakan metode penelitian normatif yang merupakan bagian dari penelitian hukum. Penelitian hukum normatif bertujuan untuk mencari solusi dari problematika yuridis yang muncul dari isu hukum dan memberikan preskripsi terhadap isu hukum tersebut. ${ }^{12}$ Penelitian hukum ditujukan untuk menemukan kebenaran koherensi yakni apakah suatu aturan hukum sesuai dengan norma hukum, adakah norma hukum tersebut sesuai dengan prinsip hukum serta apakah tindakan seseorang sesuai dengan norma hukum (bukan hanya sesuai dengan aturan hukum) atau prinsip hukum. ${ }^{13}$ Bahan primer maupun sekunder dalam penelitian ini akan dianalisis dengan memberikan gambaran atau deskripsi mengenai pendekatan harmonisasi hukum dan substansi pengaturan perwalian yang melindungi hak dan kepentingan anak melalui peran wali pengawas di Indonesia. Penelitian ini menggunakan metode penalaran deduktif induktif dalam menarik kesimpulan.

\section{Hasil Penelitian dan Pembahasan}

\subsection{Pengaturan Perwalian di Indonesia}

Perwalian merupakan salah satu bagian dari hukum keluarga. Hukum keluarga mengatur sesuatu yang menyangkut kedudukan hukum dan setiap hubungan hukum dalam lingkungan atau ruang lingkup keluarga yang meliputi perkawinan, status anak, hubungan periparan atau persemendaan, hubungan anak dengan orangtuanya (terhadap diri si anak dan harta kekayaan), hubungan anak dengan kerabatnya, tentang perwalian dan pengangkatan anak. ${ }^{14}$ Menurut Subekti, hukum keluarga mengatur perihal hubungan-hubungan hukum yang timbul dari hubungan kekeluargaan, yaitu perkawinan beserta hubungan dalam lapangan hukum kekayaan antara suami dan isteri, hubungan antara orang tua dan anak, perwalian dan curatele. ${ }^{15}$ Pembahasan mengenai perkawinan yang termasuk dalam lingkup hukum keluarga, memiliki kaitan erat dengan alasan adanya perwalian. Di mana perwalian dapat terjadi karena putusnya perkawinan, baik disebabkan karena kematian, perceraian dan atas putusan pengadilan. ${ }^{16}$ Berdasarkan Pasal 19 Peraturan Pemerintah No. 9 Tahun 1975, putusnya perkawinan merupakan suatu pengecualian dari perkawinan yang kekal dan abadi. ${ }^{17}$

\footnotetext{
12 Susanti \& Efendi. (2014). Penelitian Hukum: Legal Research. Jakarta: Sinar Grafika, hal. 1

${ }^{13}$ Marzuki. (2005). Penelitian Hukum (Edisi Revisi). Jakarta: Kencana, hal. 47

${ }^{14}$ Djuhaendah Hasan. (1998). Hukum Keluarga. Bandung: Armico, hal. 44

15 Subekti. (2003). Pokok-pokok Hukum Perdata. Jakarta: Intermasa, hal. 16

16 Indonesia, Undang-Undang Perkawinan, UU No. 1 Tahun 1974. Pasal 38 -41.

17 H. Rusdi Malik dalam Septy Veronita. (2013). "Hak Perwalian Anak di Bawah Umur yang Beralih pada Neneknya (Analisis kasus Putusan Mahkamah Agung Republik Indonesia Nomor:372K/Pdt/2008)", Tesis, Universitas Indonesia, hal. 4.
} 
Putusnya perkawinan inilah yang membawa akibat pada kedudukan anak, kekuasaan orang tua hapus dan beralih menjadi perwalian. Perihal perwalian diatur dalam peraturan perundang-undangan di Indonesia sebagai berikut:

a. Perwalian dalam Kitab Undang-Undang Hukum Perdata

Perwalian (voogdij) diartikan Subekti sebagai pengawasan terhadap anak yang di bawah umur, yang tidak berada di bawah kekuasaan orang tua serta pengurusan benda atau kekayaan anak tersebut diatur oleh undang-undang. ${ }^{18}$ Pada umumnya dalam setiap perwalian hanya ada seorang wali saja, kecuali apabila seorang wali ibu (moerdervoogdes) kawin lagi, maka suaminya menjadi wali ayah. Jika salah satu dari orang tua tersebut meninggal, maka menurut undang-undang orang tua yang masih hidup dengan sendirinya menjadi wali bagi anak-anaknya. Yang dimaksud anak dalam ketentuan tersebut ialah mereka yang belum dewasa, di mana dalam Pasal 330 KUHPerdata disebutkan yang dimaksud belum dewasa ialah "mereka yang belum mencapai umur genap dua puluh satu tahun, dan tidak lebih dahulu telah kawin". Kategori anak yang masuk dalam lingkup perwalian ialah: ${ }^{19}$

1. Anak sah yang kedua orang tuanya telah dicabut kekuasaannya sebagai orang tua;

2. Anah sah yang orang tuanya telah bercerai;

3. Anak yang lahir di luar perkawinan (natuurlijk kind).

Ruang lingkup perwalian berdasarkan Pasal 383 ayat (1) KUHPerdata, meliputi menyelenggarakan pemeliharaan dan pendidikan terhadap anak sesuai dengan kekayaannya dan dapat mewakili dalam segala tindakan atas nama anak. Kemudian dalam KUHPerdata, mengenal beberapa macam wali, yaitu:

1. Wali yang ditunjuk oleh orang tua semasa ia masih hidup (melalui surat wasiat). Pada masa orang tua masih hidup telah meunjukkan wali dari anak-anaknya kalau ia meninggal sebelum anak itu dewasa melalui akte notaris. Hal tersebut sebagaimana diatur dalam Pasal 355 ayat (1) KUHPerdata.

2. Wali menurut undang-undang. Siapa yang terlama hidup maka ia yang akan menjadi wali (ayah atau ibu) berdasarkan ketentuan dalam Pasal 345 KUHPerdata.

3. Wali diangkat oleh hakim. Orang tuanya meninggal sehingga wali ditunjuk oleh hakim. Pasal 359 KUHPerdata menentukan bahwa "semua minderjarige yang tidak berada di bawah kekuasaan orangtua dan yang diatur perwaliannya secara sah akan ditunjuk seorang wali oleh Pengadilan". Seseorang yang diangkat menjadi wali oleh hakim, harus menerima pengangkatan itu, kecuali ia seorang isteri yang kawin atau jika ia mempunyai alasan-alasan menurut undang-undang untuk minta dibebaskan dari

\footnotetext{
${ }^{18}$ Ibid, hal. 52.

19 Ibid, hal. 53.
} 
pengangkatan itu. Alasan-alasan itu antara lain jika ia, untuk kepentingan negara harus berada di luar negeri.

Selain itu terdapat golongan yang tidak dapat menjadi wali adalah orang yang sakit ingatan, orang yang belum dewasa, orang yang berada di bawah pengampuan, dan orang yang telah dicabut perwaliannya, kecuali untuk anak-anaknya. Cara penunjukan wali menurut ketentuan Pasal 51 KUHPerdata ada 3 (tiga) macam, yaitu:

1. Secara lisan di hadapan dua orang saksi;

2. Secara tertulis dengan surat wasiat;

3. Secara tertulis dengan penetapan hakim, dalam hal terjadi pencabutan kekuasaan wali.

Asas-asas perwalian terdapat dalam KUHPerdata, antara lain:20

1. Asas tak dapat dibagi-bagi (ondeelbaarheid)

Pada setiap perwalian hanya ada satu orang wali saja.

2. Asas kesepakatan dari keluarga,

Pada setiap perwalian harus mendapatkan kesepakatan dari keluarga.

Perwalian dimulai berdasarkan jenis wali tersebut, apabila wali menurut undang-undang, maka perwalian dimulai saat terjadinya peristiwa yang menimbulkan perwalian itu, misalnya kematian salah satu orang tua. Jika wali diangkat oleh hakim, maka perwalian dimulai saat pengangkatan jika ia hadir dalam pengangkatan itu. Sedangkan wali yang ditunjuk berdasarkan wasiat orang tua, maka perwalian dimulai saat orang tua itu meninggal dan sesudah wali dinyatakan menerima pengangkatan. Berdasarkan Pasal 362 KUHPerdata, wali yang diangkat, kecuali badan hukum, harus mengangkat sumpah di muka BHP. Kewajiban wali lainnya yang perlu dilaksanakan berdasarkan KUHPerdata ialah:

1. Kewajiban memberitahukan kepada BHP terkait adanya perwalian, diatur dalam Pasal 368 KUHPerdata:

"Segala wali tersebut dalam bagian ketiga bab ini, berwajib, segera setelah perwalian mulai berjalan, memberitahukan kepada Balai tentang terjadinya perwalian itu. Dalam hal dilalaikannya itu, mereka boleh dipecat, dengan tak mengurangi penggantian biaya, kerugian dan bunga".

2. Dalam tenggang waktu 3 bulan setelah terjadinya kematian wali berkewajiban mendaftarkan harta kekayaan suami/istri (Pasal 127 KUHPerdata);

3. Kewajiban mengadakan inventarisasi mengenai harta si anak yang diperwalikannya (Pasal 386 ayat (1) KUHPerdata);

4. Kewajiban-kewajiban mengadakan jaminan (Pasal 335 KUHPerdata);

\footnotetext{
20 Titik Triwulan Tuti. (2008). Hukum Perdata dalam Sistem Hukum Nasional. Jakarta: Kencana Prenadmedia Group, hal. 88-89
} 
5. Kewajiban menentukan jumlah yang dapat dipergunakan tiap-tiap tahun oleh anak tersebut dan biaya pengurusan (Pasal 338 KUHPerdata);

6. Kewajiban wali untuk mengusahakan supaya dijual segala meja kursi atau perabot rumah yang mana pada permulaan perwalian jatuh dalam kekayaan si belum dewasa, seperti segala benda tidak bergerak yang tidak memberikan hasil, pendapatan atau keuntungan, terkecuali benda-benda itulah di antaranya, yang dalam wujud boleh disimpan dengan persetujuan/izin Balai (Pasal 389 KUHPerdata);

7. Kewajiban untuk mendaftarkan surat-surat piutang negara jika ternyata dalam harta kekayaan minderjarigen ada surat piutang negara (Pasal 392 KUHPerdata);

8. Kewajiban untuk menanam (belegen) sisa uang milik minderjarigen setelah dikurangi biaya penghidupan tersebut (Pasal 371 KUHPerdata).

9. Menyelenggarakan pengurusan harta kekayaan anak di bawah umur itu dengan baik sesuai dengan undang-undang (Pasal 371 KUHPerdata);

10. Setiap tahun berkewajiban memberikan perhitungan dan tanggung jawab atas pengurusan yang sudah dilakukan (Pasal 373 jo. 409 KUHPerdata).

Selain itu, wali diwajibkan mengurus kekayaan anak yang berada di bawah pengawasan dengan sebaiknya-baiknya dan ia bertanggungjawab tentang kerugian-kerugian yang ditimbulkan karena pengurusan yang buruk. ${ }^{21}$ Namun dalam kekuasaannya, wali dibatasi oleh Pasal 393 KUHPerdata:

“Untuk kepentingan si belum dewasa, wali tak boleh meminjam uang, pun tak boleh mengasingkan atau menggadaikan barang-barangnya tak bergerak, pun pula tak boleh menjual atau memindahtangankan surat-surat utang negara, piutang-piutang dan andil-andil, tanpa mendapat kuasa untuk itu dari Pengadilan Negeri. Pengadilan takkan memberikan kuasa ini, melainkan berdasarkan atas keperluan yang mutlak atau jika terang ada manfaatnya dan setelah mendengar atau memanggil dengan sah akan para keluarga sedarah atau semenda si belum dewasa dan akan wali pengawas."

Perbuatan hukum yang dilakukan wali bukanlah penguasan mutlak yang tanpa batasan saat menjalan perwalian. Wali dapat dipecat bahkan mengganti kerugian apabila melakukan tindakan yang dianggap merugikan bagi anak. Syarat utama pemecatan wali didasarkan atas kepentingan anak itu sendiri. Alasan lain sebagai dasar memintakan pemecatan atas wali diuraikan dalam KUHPerdata, yang dirangkum sebagai berikut:22

\footnotetext{
21 Subekti, Op., Cit, hal. 54.

22 R. Soetojo Prawidohamidjojo dan Marthalena Pohan. (2008). Hukum Orang dan Keluarga (Personen en Familie-Recht). Surabaya: Airlangga University Press, hal. 231
} 
1. Jika wali berkelakuan buruk;

2. Jika dalam melaksanakan tugasnya wali tidak cakap atau menyalagunakan kecakapannya;

3. Jika wali dalam keadaan pailit;

4. Jika wali untuk dirinya sendiri atau keluarganya melakukan perlawanan terhadap si anak tersebut;

5. Jika wali dijatuhi hukuman pidana yang telah berkekuatan hukum tetap;

6. Jika wali alpa memberitahukan terjadinya perwalian kepada Balai Harta Peninggalan;

7. Jika wali tidak memberikan pertanggungjawaban kepada Balai Harta Peninggalan.

Sedangkan dalam hal berakhirnya perwalian dapat ditinjau dari dua keadaan, yaitu: 23

1. Dalam hubungan dengan keadaan si anak, berkaitan dengan si anak telah menjadi dewasa (meerderjarig), matinya anak, timbunya kembali kekuasaan orang tuanya dan pengesahan seorang anak di luar kawin yang diakui;

2. Dalam hubungan dengan tugas wali, hal ini berkaitan dengan ada pemecatan atau pembebasan atas diri si wali dan ada alasan pembebasan dan pemecatan dari perwalian (Pasal 380 KUHPerdata).

b. Perwalian dalam Kompilasi Hukum Islam

Perwalian juga diatur dalam Kompilasi Hukum Islam (selanjutnya disebut $\mathrm{KHI}$ ), yang merupakan hukum materiil bagi hakim pengadilan agama sehingga merupakan pedoman atau rujukan dalam membuat keputusan berkenaan dengan perkara yang menjadi kompetensi absolut pengadilan agama. ${ }^{24}$ Dalam KHI perwalian diartikan sebagai kewenangan yang diberikan kepada seseorang untuk melakukan sesuatu perbuatan hukum sebagai wakil untuk kepentingan dan atas nama anak yang tidak mempunyai kedua orang tua, orang tua masih hidup, dan tidak cakap melakukan perbuatan hukum. ${ }^{25}$ Ketentuan perwalian tersebut diatur dalam bab tersendiri yakni Bab XV mengenai Perwalian. Perwalian yang dimaksud dalam KHI hanya berlaku terhadap anak yang belum mencapai umur 21 tahun atau belum pernah melangsungkan perkawinan. Ruang lingkup perwalian dalam KHI berkaitan terhadap diri dan harta kekayaan anak.

Pasal $105 \mathrm{KHI}$ memberikan batasan yang jelas dan tegas sebagai pedoman hakim dalam memutus pemberian hak asuh atas anak. Dalam pasal tersebut dinyatakan bahwa:

"Dalam hal terjadi perceraian:

23 Ibid.

24 Ghulam Muhammad. (2012). "Sistem Hukum Kewarisan dalam Kompilasi Hukum Islam" dalam Zahratul Idami, Tanggungjawab Wali Terhadap Anak yang Berada Dibawah Perwaliannya (Suatu Penelitian di Kota Banda Aceh). Jurnal Dinamika Hukum, 12(1): 60-73

25 Indonesia, Kompilasi Hukum Islam, Pasal 1 huruf h. 
a. Pemeliharaan anak yang belum mummayyiz atau belum berumur 12 tahun adalah hak ibunya.

b. Pemeliharaan anak yang sudah mummayyiz diserahkan kepada anak untuk memilih di antara ayah dan ibunya sebagai pemegang hak pemeliharaan.

c. Biaya pemeliharaan ditanggung oleh ayahnya."

Wali bertanggungjawab terhadap harta anak dan mengganti kerugian terhadap harta anak sebagai akibat kesalahan atau kelalaiannya. ${ }^{26}$ Bila wali tidak mampu berbuat atau lalai melaksanakan tugas perwaliannya, maka pengadilan agama dapat menunjuk salah seorang kerabat untuk bertidak sebagai wali atas permohonan kerabat tersebut. ${ }^{27}$ Perwalian dalam KHI juga dapat dilakukan berdasarkan wasiat orang tua sesudah ia meninggal. ${ }^{28}$ Kewajiban wali dalam perwalian telah ditentukan dalam Pasal 110, yakni:

(1) Wali berkewajiban mengurus diri dan harta orang yang berada di bawah perwaliannya dengan sebaik-baiknya dan berkewajiban memberikan bimbingan agama, pendidikan dan keterampilan lainnya untuk masa depan orang yang berada di bawah perwaliannya.

(2) Wali dilarang mengikatkan, membebani dan mengasingkan harta orang yang berada dibawah perwaliannya, kecuali bila perbuatan tersebut menguntungkan bagi orang yang berada di bawah perwaliannya yang tidak dapat dihindarkan.

(3) Wali bertanggung jawab terhadap harta orang yang berada di bawah perwaliannya, dan mengganti kerugian yang timbul sebagai akibat kesalahan atau kelalaiannya.

(4) Dengan tidak mengurangi kententuan yang diatur dalam pasal 51 ayat (4) Undang-undang No.1 tahun 1974, pertanggungjawaban wali tersebut ayat (3) harus dibuktikan dengan pembukuan yang ditutup tiap satu tahun satu kali.

Alasan pencabutan perwalian dilakukan oleh Pengadilan Agama atas dasar wali pemabuk, penjudi, pemboros, gila dan/atau melalaikan atau menyalahgunakan hak dan kewenangannya sebagai wali demi kepentingan orang yang berada di bawah perwaliannya. ${ }^{29}$

c. Perwalian dalam Undang-Undang Perkawinan

Undang-undang Nomor 1 Tahun 1974 (selanjutnya disebut UU Perkawinan) mengatur ketentuan mengenai perwalian dalam Bab XI, yakni pada Pasal 50 sampai dengan Pasal 54. Berbeda dengan

26 Zahratul Idami. (2012). Tanggungjawab Wali Terhadap Anak yang Berada di Bawah Perwaliannya (Suatu Penelitian di Kota Banda Aceh). Jurnal Dinamika Hukum, 12(1): 60-73

27 Indonesia, Kompilasi Hukum Islam, Pasal 107 ayat (3).

28 Indonesia, Kompilasi Hukum Islam, Pasal 108.

${ }^{29}$ Indonesia, Kompilasi Hukum Islam, Pasal 109. 
KUHPerdata dan KHI, UU Perkawinan memiliki kategori tersendiri dalam menentukan batasan anak dalam perwalian yang diatur dalam Pasal 50 ayat (1) yang menyebutkan bahwa anak yang belum mencapai umur 18 (delapan belas) tahun atau belum pernah melangsungkan perkawinan, yang tidak berada di bawah kekuasaan orang tua, berada di bawah kekuasaan wali. Ruang lingkup perwalian dalam UU Perkawinan meliputi pribadi anak maupun harta bendanya. Pasal 52 jo. Pasal 48 UU Perkawinan mengatur bahwa wali tidak diperbolehkan memindahkan hak atau menggadaikan barang-barang tetap yang dimiliki anaknya kecuali apabila kepentingan anak itu menghendakinya.

UU Perkawinan tidak secara eksplisit mengatur mengenai wali pengawas. Namun, dengan adanya ketentuan Pasal 66 UU Perkawinan, sudah menjembatani ketentuan wali pengawas dalam KUHPerdata untuk tetap diberlakukan. ${ }^{30}$

\subsection{Peran Balai Harta Peninggalan sebagai Wali Pengawas}

Sejarah dan pembentukan BHP dimulai dengan masuknya bangsa Belanda ke Indonesia. Pada mulanya bangsa Belanda datang sebagai pedagang dan bersaing dengan pedagang asing lainnya, seperti Cina, Inggris, dan Portugis yang memiliki armada-armada besar. Untuk menghadapi persaingan tersebut Belanda pada tahun 1602 mendirikan perkumpulan dagang yang diberi nama Vereenigde Oost Indische Companie (VOC). Selain bertujuan untuk berdagang di Indonesia, VOC juga memiliki maksud untuk melakukan penjajahan di Indonesia. ${ }^{31}$

Kekuasaan VOC lambat laun semakin luas, hingga timbul kebutuhan bagi para anggotanya khususnya dalam hal mengurus harta kekayaan yang ditinggalkan oleh mereka dan bagi kepentingan para ahli waris yang berada di Nederland, anak-anak yatim piatu dan sebagainya. Untuk memenuhi kebutuhan itu, Pemerintah Belanda membentuk lembaga yang diberi nama Wees-en Boedelkamer atau Weskamer (Balai Harta Peninggalan). BHP pertama kali didirikan di Jakarta yakni tanggal 1 Oktober 1624. Sedangkan pendirian BHP di daerah lain sejalan pula dengan kemajuan teritorial yang dikuasai VOC, untuk memenuhi kebutuhannya. ${ }^{32}$

Berdasarkan Pasal 1 ayat (1) Keputusan Menteri Kehakiman RI Nomor M.01.PR.07.01-80 Tahun 1980 tanggal 19 Juni 1980 tentang Organisasi dan Tata Kerja Balai Harta Peninggalan menentukan bahwa BHP adalah unit pelaksana penyelenggara hukum di bidang harta peninggalan dan perwalian dalam lingkungan Departemen Kehakiman, yang berada di bawah dan bertanggungjawab langsung kepada Direktur Jenderal Hukum dan Peraturan

\footnotetext{
30 Endang Heriyani dan Prihati Yuniarlin. (2013). Fungsi BHP sebagai Wali Pengawas Terhadap Anak di Bawah Perwalian dalam Rangka Perlindungan anak. Jurnal Media Hukum, 22(2): 218 - 231

${ }^{31}$ Lihat Buku Panduan Praktis Balai Harta Peninggalan Surabaya (Fungsi dan Tugas Pokoknya).

32 Departemen Kehakiman Republik Indonesia, Direktorat Jenderal Hukum dan Perundang-Undangan, Himpunan Peraturan Perundang-Undangan Balai Harta Peninggalan (Buku I), hal. 11-12.
} 
Perundang-Undangan melalui Direktur Perdata. ${ }^{33}$ BHP sebagai lembaga yang menyelenggarakan pengurusan dan pengelolaan harta kekayaan dalam perwalian, pengampuan, ketidakhadiran, harta peninggalan yang tidak terurus, titipan daluwarsa, dana transfer tunai yang tidak diambil, uang yang berasal dari jaminan sosial tenaga kerja yang tidak diambil, pewarisan, dan kepailitan. ${ }^{34}$

Kehadiran BHP di Indonesia mengalami masa pasang surut, yakni dengan penghapusan BHP Ujung Pandang dan perwakilan-perwakilannya dengan Surat Keputusan Menteri Kehakiman RI tanggal 12 Oktober 1964 Nomor J.A.10/11/24. Kemudian pada tahun 1976 oleh Menteri Kehakiman yang pada waktu itu dijabat oleh Mochtar Kusumaatmadja dirasa perlu untuk membentuk kembali BHP Ujung Pandang dan perwakilan-perwakilannya, maka dengan Surat Keputusan Menteri Kehakiman tanggal 23 Oktober 1976 No. J.S.4/9/1 telah dibentuk kembali BHP Ujung Pandang dan perwakilanperwakilannya. Selanjutnya dengan Surat Keputusan Menteri Kehakiman masing-masing:

1. Tanggal 5 Nopember 1986 No. M.02-PR.07.01 Tahun1986 ;

2. Tanggal 1 April 1987 No. M.01-PR.0.01 Tahun 1987 ;

3. Tanggal 29 Juni 1987 No. M.04-PR.07.01 Tahun 1987 ;

4. Tanggal 5 September 1987 No. M.06-PR.07.01 Tahun 1987.35

BHP sebagai unit pelaksana teknis di lingkungan Kementerian Hukum dan Hak Asasi Manusia Republik Indonesia, melaksanakan tugas dan fungsinya sesuai dengan visi memberikan perlindungan/terayominya Hak Asasi Manusia, khususnya yang oleh hukum dan penetapan pengadilan dianggap tidak cakap bertindak di bidang hak milik. Fungsi BHP tersebut sebagaimana ditetapkan dalam Bab I Pasal 3 Keputusan Menteri Kehakiman RI Nomor: M.01.PR.07.01-80 Tahun 1980 tanggal 19 Juni 1980 tentang Kedudukan, Tugas dan Fungsi Organisasi BHP. Adapun fungsi tersebut antara lain:

a. Melaksanakan penyelesaian masalah perwalian, pengampuan, ketidakhadiran dan harta peninggalan yang tidak ada kuasanya dan lain-lain masalah yang diatur dalam perundang-undangan;

b. Melaksanakan penyelesaian pembukaan dan pendaftaran surat wasiat sesuai dengan peraturan-perundang-undangan;

c. Melaksanakan penyelesaian masalah kepailitan sesuai dengan peraturan perundang-undangan.

Dalam bidang perwalian, tugas BHP sebagai wali pengawas diatur dalam Pasal 366 KUH Perdata yang menyebutkan bahwa dalam tiap-tiap perwalian yang diperintahkan di Indonesia, BHP berkewajiban melakukan

\footnotetext{
33 Indonesia, Keputusan Menteri Kehakiman RI Nomor M.01.PR.07.01-80 Tahun 1980 tentang Organisasi dan Tata Kerja Balai Harta Peninggalan.

34 Ibid.

${ }^{35}$ Departemen Kehakiman Republik Indonesia, Direktorat Jenderal Hukum dan Perundang-Undangan, Op., Cit., hal. 13.
} 
tugas wali pengawas. Selain BHP, terdapat juga Baitul Mal ${ }^{36}$ yang dikhususkan untuk orang muslim di Aceh sedangkan untuk non muslim tunduk pada BHP. ${ }^{37}$ Dengan demikian Baitul Mal juga mempunyai kewenangan yang sama dengan BHP sebagai wali pengawas terhadap anak yatim piatu yang masih di bawah umur. ${ }^{38}$

Tugas sebagai wali pengawas ini BHP bertindak untuk mengamati apakah wali melaksanakan kewajiban dengan baik atau tidak dan seberapa perlu memberikan nasihat kepada wali untuk melakukan kewajiban dengan sebaik-baiknya. ${ }^{39}$ Peran BHP sebagai wali pengawas antara lain:

a. Menyumpah wali dan membuatkan Berita Acara Sumpah (Pasal 362 KUHPerdata);

b. Menyelenggarakan pendaftaran harta kekayaan yang di dalamnya berkepentingan anak belum dewasa (Pasal 127 KUHPerdata);

c. Mewakili kepentingan anak belum dewasa, apabila kepentingan mereka bertentangan dengan walinya (Pasal 370 KUHPerdata);

d. Mengawasi wali untuk membuat pendaftaran harta kekayaan anak (Pasal 370 ayat (2) KUHPerdata);

e. Meminta kepada wali untuk menyediakan jaminan secukupnya (Pasal 371 KUHPerdata);

f. Meminta perhitungan dan tanggungjawab dari wali (Pasal 372 KUHPerdata);

g. Mengajukan usul kepada Pengadilan Negeri untuk memecat wali dan mengajukan calon wali yang baru (Pasal 373 KUHPerdata);

h. Memberi keterangan kepada hakim tentang bermanfaat tidaknya penjualan barang yang didalamnya berkepentingan anak belum dewasa (Pasal 393 KUHPerdata);

i. Mewakili anak belum dewasa melakukan perjanjian sewa menyewa apabila penyewanya adalah wali sendiri (Pasal 400 KUHPerdata);

j. Memberikan kuasa kepada wali untuk bertindak sebagai penggugat maupun tergugat dalam perkara perdata guna kepentingan anak yang belum dewasa (Pasal 403 KUHPerdata);

k. Menghadiri acara pemisahan dan pembagian harta kekayaan yang di dalamnya berkepentingan anak belum dewasa (Pasal 406 KUHPerdata);

Pengangkatan wali pengawas harus selalu terjadi dalam setiap perwalian. Wali wajib menjaga adanya wali pengawas. ${ }^{40}$ Sebagaimana

\footnotetext{
36 Baitul Mal adalah Balai Harta Keagamaan, lihat Pasal 171 huruf I Kompilasi Hukum Islam.

37 Indonesia, Undang-Undang Nomor 48 Tahun 2007 tentang Penetapan Peraturan Pemerintah Pengganti Undang-Undang Nomor 2 Tahun 2007 tentang Penanganan Permasalahan Hukum dalam Rangka Pelaksanaan Rehabilitasi dan Rekonstruksi Wilayah dan Kehidupan Masyarakat di Provinsi Nanggroe Aceh Darussalam dan Kepulauan Nias Provinsi Sumatera Utara menjadi Undang-Undang, LNRI Tahun 2007 Nomor 168 dan TLN Nomor 4796.

38 Yudhi Marza Harca. (2013). Tinjauan Yuridis Pelaksanaan Perwalian Terhadap Anak dibawah umur Korban Tsunami di Aceh. Tesis Fakultas Hukum Universitas Sumatera Utara, hal. 100

${ }^{39}$ Nurhendro Putrant. (2013). Balai Harta Peninggalan Fungsi dan Tugas Pokoknya (Edisi Revisi), hal. 16

40 R. Soetojo Prawidohamidjojo dan Marthalena Pohan, Op., Cit., hal. 233.
} 
dikatakan di atas, bila wali tidak memberitahukan kepada BHP tentang terjadinya perwalian, maka wali itu dapat dipecat. R. Soetojo menguraikan kewajiban dari wali pengawas, antara lain: ${ }^{11}$

a. Mengadakan pengawasan terus terhadap wali;

b. Menyatakan pendapatnya terhadap berbagai tindakan yang harus dilakukan oleh wali atas perintah hakim atau dengan persetujuan hakim;

c. Bertindak bersama-sama dengan wali atau ikut hadir dalam tindakan-tindakan tertentu;

d. Bertindak bila ada kepentingan yang bertentangan antara wali dengan minderjarige; dan

e. Bertindak bila wali tidak hadir atau perwalian itu terluang.

Berdasarkan hasil penelitian serupa yang dilakukan Taufik $\mathrm{H}$. Simatupang mengenai efektifitas dan efisiensi pelaksanaan tugas dan fungsi di BHP selama ini, khususnya mengenai perwalian menunjukan bahwa mayoritas responden, yakni sebanyak 15 orang, pernah ditunjuk sebagai wali pengawas. Sedangkan 12 orang responden lainnya belum pernah ditunjuk. ${ }^{42}$ Jika sekilas data tersebut menunjukkan lebih banyak responden yang pernah menjadi wali pengawas, namun jika dikaitkan dengan banyaknya data kematian orang tua yang dimiliki oleh Dinas Pendudukan dan Catatan Sipil dan penetapan perwalian dan/atau izin jual di Pengadilan Negeri, berbanding terbalik dengan pelaksanaan peran wali pengawas.

Peran wali pengawas untuk melindungi kepentingan anak tidak berjalan dengan baik. Kewajiban wali untuk diambil sumpah oleh BHP selaku wali pengawas pun tidak terlaksana. Di mana sumpah tersebut merupakan suatu pernyataan yang khidmat yang diberikan atau diucapkan pada saat memberi janji atau keterangan dengan mengingat akan sifat maha kuasa dari Tuhan ${ }^{43}$ bahwa wali akan menjalankan perwalian yang dipercayakan kepadanya dengan baik dan tulus hati. Pengawasan oleh negara ini bukan tanpa akibat hukum apabila tidak dilaksanakan bagi wali yang tidak memberitahukan perwalian dan bagi perbuatan hukum maupun perjanjian yang dilakukan. Dalam Pasal 368 KUHPerdata, telah disebutkan apabila wali lalai dalam memberitahukan kepada BHP, maka wali dapat dipecat dengan mengganti biaya, kerugian, dan bunga. Berkaitan dengan perbuatan hukum maupun perjanjian yang dilakukan oleh wali yang mengesampingkan BHP, Pasal 418 KUHPerdata mengatur sebagai berikut:

"Balai-balai dan dewan-dewan tidak boleh dikesampingkan dari segala campur tangan yang diperintahkan kepada mereka dalam ketentuan undangundang. Segala perbuatan dan perjanjian bertentangan dengan ketentuan di atas adalah batal dan tak berharga".

41 Ibid.

42 Taufik H. Simatupang. (2018). Eksistensi dan Efektivitas Pelaksanaan Tugas Balai Harta Peninggalan di Indonesia. Jurnal Penelitian Hukum De Jure, 18(3): 397-414..

43 Sudikno Mertokusumo. (2010). Hukum Acara Perdata Indonesia. Yogyakarta: Universitas Atma Jaya, hal. 256 
Berdasarkan 2 (dua) ketentuan tersebut sebenarnya dapat memaksa untuk ditaatinya proses perwalian anak dibawah umur dengan peran serta wali pengawas. Namun, hal tersebut membutuhkan peran serta instansi atau pihak lainnya yang memiliki hubungan kerja dengan BHP, seperti Pengadilan Negeri, Dinas Pendudukan dan Pencatatan Sipil, Notaris/PPAT, dan BPN untuk menutup peluang perbuatan hukum wali yang dilakukan tanpa peran serta BHP sebagai wali pengawas.

\section{Harmonisasi Perlindungan Harta Kekayaan Anak dalam Perwalian Melalui Penguatan Peran Wali Pengawas}

Ruang lingkup perwalian pada dasarnya perlindungan dan pengurusan terhadap pribadi anak dan harta anak. Pribadi anak berkaitan dengan pemenuhan untuk mendapatkan pendidikan, sandang, pangan, sehat jasmani rohani, dan rasa aman. Sedangkan mengenai harta kekayaan anak dalam Pasal 33 ayat (4) Undang-Undang Nomor 23 Tahun 2002 tentang Perlindungan Anak (Selanjutnya disebut UU Perlindungan Anak), wali mempunyai kewajiban mengelola harta milik anak yang bersangkutan. Dalam Pasal 52 jo. Pasal 48 KUHPerdata sebenarnya sudah diatur bahwa wali dilarang untuk memindahtangankan hak atau menggadaikan barang-barang tetap milik si anak yang masih di bawah kekuasaannya. Tanggung jawab perlindungan anak diusahakan setiap orang baik orangtua, keluarga masyarakat, pemerintah, maupun negara. Oleh karena itu, sekalipun perlindungan terhadap harta kekayaan anak dalam pelaksanaannya tidak terlepas dari prinsip-prinsip perlindungan anak, antara lain: ${ }^{44}$

1. Anak tidak dapat berjuang sendiri

Anak tidak dapat melindungi sendiri hak-haknya, banyak pihak yang mempegaruhi kehidupannya.

2. Kepentingan terbaik bagi anak (The Best Interest of the Child) Prinsip ini dipandang sebagai of paramount importence dalam setiap keputusan yang menyangkut anak.

3. Ancangan daur kehidupan (life-circle approach)

Perlindungan anak mengacu pada pemahaman bahwa perlindungan harus dimulai sejak dini dan secara terus menerus.

4. Lintas sektoral

Nasib anak bergantung pada aspek makro dan mikro, baik langsung maupun tidak langsung. Oleh karena jaminan perlindungan bagi anak membutuhkan peran oleh berbagai sektor.

Ketidakcakapan anak dalam perwalian memiliki konsekuensi si anak tidak dapat melakukan perbuatan hukum atas dirinya sendiri. Dalam hal ini perbuatan hukum terhadap harta kekayaan anak tersebut diwakili dan dikelola oleh wali. Namun perlu dipahami bahwa Pasal 393 KUHPerdata memberikan batasan terhadap perbuatan hukum yang dilarang dilakukan wali, kecuali mendapatkan izin atas dasar penetapan Pengadilan Negeri.

${ }^{44}$ Arif Gosita, Op., Cit., hal. 35. 
Perwalian tidak lain merupakan suatu perbuatan hukum yang melahirkan akibat hukum berupa hak dan kewajiban, oleh karena itu dalam pelaksanaanya dituntut harus sesuai dengan aturan hukum yang berlaku. Sering orang berbicara atau bahkan mengemban tugas dan kewajiban sebagai wali tidak pernah mengetahui secara tepat bagaimana perwalian itu dilaksanakan sesuai dengan ketentuan hukum yang berlaku. Sehingga terjadi tindakan-tindakan yang justru menyimpang dari tujuan sesungguhnya dari perwalian. ${ }^{45}$ Padahal aturan hukum mengenai perwalian telah lama ada sebagaimana tercantum dalam beberapa peraturan perundang-undangan yang berlaku sepeti KUHPerdata, KHI, UU Perkawinan dan UU Perlindungan Anak. Ketentuan yang ada masih mengandung kelemahan dan kekurangan yang menyebabkan perlindungan atas harta anak yang berada di bawah perwalian menjadi tidak sempurna atau lebih dari itu menjadi tidak terlindungi sama sekali. ${ }^{46}$

Pasal 366 KUHPerdata seolah tidak memiliki daya guna. ${ }^{47}$ Sejumlah persoalan yang terkait dengan kepastian/ketidakjelasan aturan dipaksakan untuk tetap dilaksanakan. Pasal 393 KUHPerdata mengenai larangan wali terhadap harta kekayaan anak tidak dapat terkontrol dan diawasi oleh wali pengawas. Sebab campur tangan wali pengawas hilang manakala tidak ada pemberitahuan yang dilakukan oleh wali ${ }^{48}$ dan tidak diterimanya salinan penetapan dari Pengadilan Negeri ${ }^{49}$ yang membuat penetapan perwalian dan/atau izin jual. Pada proses selanjutnya, seperti pelaksanaan menjual atau menggadaikan benda-benda milik anak, masih berlangsung tanpa sepengetahuan wali pengawas. Hal ini berkaitan dengan terbukanya peluang untuk tidak melibatkan wali pengawas yang sebenarnya hal tersebut bertentangan dengan Pasal 393 jo. Pasal 395 jo. Pasal 418 KUHPerdata. Kondisi tersebut terjadi berkaitan dengan peran wali pengawas yang tidak dapat berdiri sendiri. Untuk melakukan peran sebagai wali pengawas, BHP membutuhkan peran dari lembaga lain seperti Dinas Kependudukan dan Pencatatan Sipil dengan laporannya, Pengadilan Negeri dengan salinan penetapannya dan Notaris/PPAT dengan persyaratan pengurusannya. Hubungan kerja BHP selaku wali pengawas dan instansi lainnya dapat diuraikan sebagai berikut:

\section{a. Dinas Kependudukan dan Catatan Sipil}

Hubungan kerja BHP dengan Dinas Kependudukan dan Catatan Sipil, yang diatur dalam undang-undang mengenai: ${ }^{50}$

\footnotetext{
45 Septy Veronita, Op., Cit., hal. 40.

46 Al Yasa' Abubakar. (2011). Perlindungan Harta Anak dalam Peraturan Perundang-Undangan dan Praktek di Mahkamah Syar'iyah. Jurnal Ilmiah Islam Futura, 10(2): 1-19

47 Maria Farida Indrati. (2007). Ilmu Perundang-Undangan 1: Jenis, Fungsi dan Materi Muatan, Yogyakarta:

Kanisius, hal. 39

48 Indonesia, Kitab Undang-Undang Hukum Perdata, Pasal 368.

49 Indonesia, Kitab Undang-Undang Hukum Perdata, Pasal 369

50 Nurhendro Putranto, Op., Cit., hal. 9.
} 
1) Laporan kematian, sebagaimana diatur dalam Stbl. 1917 No. 130 jo. Stbl. 1919 No. 81 jo. Pasal 360 KUHPerdata;

2) Laporan kelahiran anak luar nikah, sebagaimana diatur dalam Stbl. 1917 No. 130 Jo. 1919 No. 81;

3) Laporan perwalian kedua dan seterusnya, sebagaimana diatur dalam Pasal 60 KUHPerdata;

4) Laporan Pengakuan Anak, sebagaimana diatur dalam Stbl. 1917 No. 130 jo. Stbl. 1919 No.81;

5) Laporan Perceraian, sebagaimana diatur dalam Stbl. 1917 No. 130 jo. Stbl 1919 No. 81;

Dengan berlakunya undang-undang otonomi daerah, kantor catatan sipil yang semula merupakan bagian dari Kementerian Dalam Negeri, menjadi di bawah kewenangan Kepala Daerah setempat. Akibatnya di beberapa daerah mempunyai nama berlainan dan/atau tupoksinya ditambah. 51 UndangUndang Nomor 23 Tahun 2006 tentang Administrasi Kependudukan (selanjutnya disebut UU Adminduk), di mana banyak yang beranggapan tidak perlu memberi laporan kepada BHP. Hal ini berkaitan dengan ketentuan penutup pada Pasal 106 UU Adminduk, yang menyebutkan:

"Pada saat Undang-Undang ini mulai berlaku:

b. Buku Kesatu Bab Kedua Bagian Kedua dan Bab Ketiga Kitab UndangUndang Hukum Perdata (Burgerlijk Wetboek voor Indonesie, Staatsblad 1847:23);

c. Peraturan Pencatatan Sipil untuk Golongan Eropa (Reglement op het Holden der Registers van den Burgerlijken Stand voor Europeanen, Staatsblad 1849:25 sebagaimana telah diubah terakhir dengan Staatsblad 1946:136);

d. Peraturan Pencatatan Sipil untuk Golongan Cina (Bepalingen voor Geheel Indonesie Betreffende het Burgerlijken Handelsrecht van de Chinezean, Staatsblad 1917:129 jo. Staatsblad 1939:288 sebagaimana diubah terakhir dengan Staatsblad 1946:136);

e. Peraturan Pencatatan Sipil untuk Golongan Indonesia (Reglement op het Holden van de Registers van den Burgerlijeken Stand voor Eenigle Groepen v.d nit tot de Onderhoringer van een Zelfbestuur, behoorende Ind. Bevolking van Java en Madura,Staatsblad 1920:751 jo. Staatsblad 1927:564);

f. Peraturan Pencatatan Sipil untuk Golongan Kristen Indonesia (Huwelijksordonantie voor Christenen Indonesiers Java, Minahasa en Amboiena, Staatsblad 1933:74 jo. Staatsblad 1936:607 sebagaimana diubah terakhir dengan Staatsblad 1939:288);

g. Undang-Undang Nomor 4 Tahun 1961 tentang Perubahan atau Penambahan Nama Keluarga (Lembaran Negara Tahun 1961 Nomor 15, Tambahan Lembaran Negara Nomor 2154). dicabut dan dinyatakan tidak berlaku."

Berkaitan dengan UU Adminduk tersebut, kantor catatan sipil yang pada saat ini bernama Dinas Kependudukan dan Catatan Sipil masih memiliki

51 Ibid, hal. 10. 
hubungan kerja dengan BHP, dalam hal memberitahukan laporan yang berkaitan dengan perwalian. Hal ini berkaitan pada Pasal 106 huruf a UU Adminduk tersebut hanya mencabut ketentuan dalam buku kesatu bab kedua bagian kedua dan bab ketiga KUHperdata. Di mana ketentuan yang dicabut buku kesatu bab kedua bagian kedua mengenai nama-nama, perubahan nama-nama dan perubahan nama-nama depan, dan bab ketiga mengenai tempat tinggal atau domisili. Sedangkan bab kelima belas tentang Kebelumdewasaan dan perwalian tetap berlaku, khususnya pada Pasal 360 KUHPerdata yang menyebutkan:

“Pegawai Catatan Sipil berkewajiban memberitahukan kepala Balai Harta Peninggalan kematian yang harus dibukukan dalam register, dengan pertelaan disamping itu, apakah orang-orang yang meninggal itu meninggalkan anak-anak belum dewasa, dan memberitahukan pula perlangsungan segala perkawinan yang akan dibukukan mengenai orangtuaorangtua yang mempunyai anak-anak belum dewasa"

Sinergitas tugas Dinas Kependudukan dan Catatan Sipil dengan tugas BHP sebagai wali pengawas apabila dilakukan akan sangat bermanfaat untuk melindungi anak dalam perwalian. Laporan tersebut dapat menjadi dasar untuk mengetahui jumlah anak yang masuk dalam kategori perwalian sehingga segera mungkin dapat dilakukan pengawasan termasuk untuk kegiatan pencatatan harta kekayaan anak.

\section{b. Pengadilan Negeri}

KUHPerdata memuat beberapa ketentuan yang mengatur hubungan kerja antara BHP dengan Pengadilan Negeri. Sebagaimana Pasal 373 KUHPerdata dalam hal pemecatan wali jika wali itu menolak menjalankan tugas yang telah dibebankan kepadanya dan lalai melaksanakan tugas-tugasnya. Pasal 374 KUHPerdata mengenai pengangkatan wali baru atau wali sementara apabila wali tidak melakukan tugasnya untuk sementara waktu BHP selaku wali pengawas berhak mengajukan ke pengadilan.

Pengawasan terhadap harta kekayaan anak-anak di bawah umur sebagaimana diatur dalam Pasal 370 KUHPerdata, yaitu wali pengawas berkewajiban memerintahkan wali untuk membuat perhitungan dan barang serta harta peninggalan kepunyaan anak belum dewasa walaupun hukum tidak memerintahkannya. Namun, hubungan kerja dengan Pengadilan Negeri tidak berjalan sebagaimana diatur dalam peraturan, sebagai contoh ialah:

a. Putusan Pengadilan Negeri dalam pengangkatan wali sebagai akibat putusnya perkawinan. Pengadilan Negeri jarang sekali mengirimkan salinan putusan tersebut kepada Balai Harta Peninggalan sebagai wali pengawas terhadap anak-anak di bawah umur yang berada dalam perwalian, ketentuan Pasal 362 agar wali disumpah dihadapan Balai Harta 
Peninggalan tidak dapat dilaksanakan karena Balai Harta Peninggalan tidak mengetahuinya adanya perwalian. ${ }^{52}$

b. Izin menjual harta kayaan anak-anak di bawah umur yang diajukan oleh wali ke Pengadilan Negeri dan Pengadilan Negeri tidak pernah memanggil atau menghubungi Balai Harta Peninggalan terlebih dahulu sebelum memberikan izin penjualan dan langsung saja mengabulkan permohonan wali. ${ }^{53}$ Hal tersebut telah mengindahkan ketentuan dalam Pasal 393 KUHPerdata yang menyatakan “....Pengadilan takkan memberikan kuasa ini, melainkan berdasar atas keperluan yang mutlak, atau jika terang ada manfaatnya dan setelah mendengar atau memanggil dengan sah akan para keluarga sedarah atau semenda si belum dewasa

Dari beberapa contoh tersebut, Pengadilan Negeri tidak sungguh-sungguh melaksanakan aturan-aturan yang ada dalam undang-undang khsusnya aturan mengenai perwalian pengawas dan sangat mengurangi pelaksanaan tugas BHP. 54

\section{c. Notaris/PPAT}

Notaris adalah pejabat umum yang berwenang untuk membuat akta otentik dan kewenangan lainya yang dimaksud dalam Undang-Undang Nomor 30 Tahun 2004 tentang Jabatan Notaris (selanjutnya disebut UU Jabatan Notaris). Notaris memiliki keterkaitan dalam hal perwalian apabila perwalian tersebut dilakukan atas dasar adanya wasiat. Berdasarkan Pasal 16 huruf i dan j Undang-Undang No. 2 Tahun 2014 tentang Perubahan atas UU Jabatan Notaris, Notaris wajib membuat daftar akta yang berkenaan dengan wasiat dan mengirimkannya ke pusat daftar wasiat. Pasal 943 KUHPerdata mengatur bahwa tiap-tiap Notaris yang menyimpan wasiat, dalam bentuk apa pun juga harus setelah si yang mewariskan meninggal dunia, memberitahukannya kepada semua yang berkepentingan. ${ }^{55}$ Perihal ahli waris masih di bawah umur dan dalam perwalian orang tua yang masih hidup maka notaris juga perlu melaporkannya kepada BHP bersamaan dengan dikirimkannya daftar wasiat pada BHP. 56

Fungsi akta PPAT dalam jual beli, Mahkamah Agung dalam Putusan Nomor 1363/K/Sip/1997 berpendapat bahwa Pasal 19 Peraturan Pemerintah Nomor 10 Tahun 1961 secara jelas menentukan bahwa akta PPAT hanya suatu alat bukti dan tidak menyebut bahwa akta itu adalah syarat mutlak sahnya jual beli tanah. ${ }^{57}$ Peran PPAT dalam perwalian ini erat kaitannya dalam hal memilah pengajuan akta jual beli yang berkaitan dengan harta kekayaan anak.

\footnotetext{
52 Patimah Sari. (2017). Peranan Balai Harta Peninggalan dalam Perwalian Berdasarkan Sistem Hukum Perdata Indonesia (Studi Balai Harta Peninggalan Medan). Skripsi Fakultas Hukum Universitas Sumatera Utara, hal. 74 53 Ibid.

54 Ibid.

55 Fanny Levla. (2017). Tanggung Gugat Notaris dalam Pelaksanaan Pendaftaran Wasiat secara Online. Jurnal Arena Hukum, 10(1): 141-162

56 Ibid.

57 Budi Harsono. (2008). Hukum Agraria Indonesia: Sejarah Pembentukan Undang-Undang Pokok Agraria, Isi dan Pelaksanaannya. Jakarta: Djambatan, hal. 372
} 
Anak di bawah umur tidak dapat pengajuan permohonan perdaftaran tanah begitu juga tidak dapat melakukan perbuatan hukum tanpa diwakilkan oleh orang tuanya atau walinya berkaitan dengan Pasal 1320 KUHPerdata. Apabila anak di bawah umur tetap mengajukan permohonan hak atas tanah, melakukan perbuatan hukum atas tanah, maka akan ditolak oleh Kantor Pertanahan atau Notaris/PPAT kecuali diwakilkan oleh orang tua atau walinya. Sedang orang tua atau walinya hendak memindahkan/mengalihkan hak, termasuk mengagunkan tanah yang pemilik/pemegang haknya termasuk anak di bawah umur, baik pemilikan sendiri atau pemilikan bersama, maka haruslah terlebih dahulu mendapatkan izin pengadilan, tanpa izin tersebut pendaftaran peralihan, pemindahan hak atau pembebanannya akan ditolak oleh Kantor Pertanahan. Persyaratan yang dibutuhkan dalam pengurusan akta di PPAT berdasarkan pada penetapan yang wali dan izin jual dari Pengadilan Negeri ${ }^{58}$, yang notabene penetapan tersebut juga luput dari pertimbangan wali pengawas.

\section{d. Badan Pertanahan Nasional}

Peran BPN dalam menghadapi permasalahan pendaftaran tanah yang masuk lingkup harta kekayaan anak di bawah umur juga tidak lepas kaitannya dengan perwalian. Usaha untuk menghindari terjadinya sengketa sertipikat hak atas tanah yang didaftarakan oleh wali terhadap anak dibawah umur sebenarnya dapat dilakukan sejak awal, dan secara preventif pada saat permohonan pemberian hak dalam proses pendaftaran tanah milik. Tindakan preventif ini sebenarnya lebih efektif dibandingkan dengan usaha penyelesaian sengketa apabila masalah tersebut telah menjadi kasus (represif), dengan tidak mengesampingkan usaha teknis lain berupa pembinaan peraturan serta ketentuan yang ada.

Proses pemberian sertipikat melalui pendaftaran tidak semata-mata hanya dilihat dari segi prosedurnya saja. Suatu permohonan penerbitan sertipikat tidak cukup hanya dianalisa dengan apakah si pemohon memenuhi syarat, permohonan tersebut diumumkan, diperiksa secara fisik, dan lain sebagainya yang bersifat prosedur seperti pesertipikatan tanah, melainkan juga dikaji dari segi hukumnya. Suatu permohonan dapat dinilai menurut hukum layak untuk diproses, apabila subyek permohonan dapat membuktikan secara hukum bahwa ia adalah pihak yang satu-satunya berhak atas yang dimohonnya.

Penilaian terhadap pembuktian yang dilakukan oleh aparat Badan Pertanahan nasional / Kantor Pertanahan terhadap permohonan tersebut, adalah dari segi riwayat perolehan tanah kepada yang bersangkutan secara sah dan dapat dipertanggungjawabkan. Di sinilah diperlukan aspek perdata di dalam suatu permohonan penerbitan sertipikat balik nama. Pejabat Badan Pertanahan

\footnotetext{
58 Elita Savira, dkk., Penetapan Perwalian Anak yang diminta PPAT sebagai Syarat Pembuatan Akta Jual Belu Hak Atas Tanah, Artikel, Program Studi Magister Kenotariatan Pascasarjana, Fakultas Hukum Universitas Brawijaya, hal. 10.
} 
Nasional/Kantor Pertanahan yang berwenang harus menerapkan ketentuanketentuan peraturan maupun hukum yang mengatur, misalnya pesertipikatan tanah hak milik, tanah hak milik yang dilakukan dihadapan PPAT.59 Penilaian terhadap pembuktian yang dilakukan oleh kantor pertanahan inilah yang sebenarnya menjadi momentum untuk melibatkan peran wali pengawas dalam memberikan pertimbangan terkait harta kekayaan anak.

Di sisi lain, kondisi yang kurang sinergi antar lembaga dapat mengurangi tingkat kepercayaan masyarakat kepada hukum dan instansi pemerintahan. Hal ini berkaitan dengan penilaian akuntabilitas kinerja para instansi terkait dalam memberikan perlindungan hukum bagi warganya, yang dalam hal ini berkaitan dengan perlindungan harta kekayaan anak yang notabene tidak cakap dan membutuhkan pengawasan dalam pelaksanaannya. Tanpa sinergitas antara instansi untuk mewujudkan rangkaian tata pemerintahan yang baik akan berpengaruh pada akuntabilitas masing-masing instansi. Tanpa akuntabilitas, maka hampir seluruh tahap dan fase dalam proses hukum akan dirasakan sebagai lorong gelap yang mencekam dan penuh teka teki, sehingga pencari keadilan dihantui kecemasan, ketakutan dan ketidakjelasan. ${ }^{60}$ Disharmoni pelaksanaan peran masing-masing lembaga dalam kerangka perwalian ini diharapkan dapat berakhir melalui harmonisasi hukum.

Harmonisasi hukum dikembangkan dalam ilmu hukum yang digunakan untuk menunjukkan bahwa dalam dunia hukum, kebijakan pemerintah dan hubungan di antara keduanya terdapat keanekaragaman yang dapat mengakibatkan disharmoni. ${ }^{61}$ Rudolf Stammler mengemukakan suatu konsep fungsi hukum, bahwa tujuan atau fungsi hukum adalah harmonisasi berbagai maksud, tujuan dan kepentingan antara individu dengan individu dan antara individu dengan masyarakat. ${ }^{62}$

Penerapan peraturan perundang-undangan dalam jumlah banyak secara bersamaan dalam waktu yang sama dan dalam ruang yang sama, membawa konsekuensi terjadinya disharmoni hukum, misalnya terjadinya tumpang tindih kewenangan dan benturan kepentingan. Penerapan berbagai macam peraturan perundang-undangan secara bersama-sama tanpa upaya-upaya harmonisasi hukum atau penyelarasan dan penyerasian sudah tentu akan menimbulkan benturan kepentingan antar lembaga. ${ }^{63}$ Potensi terjadinya disharmoni hukum tercermin oleh adanya faktor-faktor, sebagai berikut:

1) Jumlah peraturan perundang-undangan yang banyak berlaku dalam tata pemerintahan;

2) Perbedaan kepentingan dan perbedaan penfsiran;

\footnotetext{
${ }^{59}$ Adrian Sutedi. Peralihan Hak Atas Tanah dan Pendaftarannya. (2007). Jakarta: Sinar Grafika, hal. 262

60 Bernard L. Tanya. (2011). Penegakan Hukum dalam Terang Etika. Yogyakarta: Genta, hal. 23

61 Kusnu Goesniadhie S. (2006). Harmonisasi Hukum dalam Perspektif Perundang-undangan, Lex Specialis Suatu Masalah, Surabaya: JPBooks, hal 62

62 Kusnu Goesniadhie S, Op., Cit., hal. 2.

63 Ibid, hal. 9.
} 
3) Kesenjangan antara pemahaman teknis dan pemahaman hukum tentang tata pemerintahan yang baik;

4) Kendala hukum yang dihadapi dalam penerapan peraturan perundangundangan yang terdiri atas mekanisme pengaturan, administrasi pengaturan, antisipasi terhadap perubahan dan penegakan hukum;

5) Hambatan hukum yang dihadapi dalam penerapan peraturan perundang-undangan, yaitu berupa tumpang tindih kewengan dalam benturan kepentingan.

Berkaitan dengan disharmoni yang terjadi dalam perlindungan harta kekayaan anak yang melibatkan peran wali pengawas, berkaitan dengan beberapa faktor:

1) Faktor adanya perbedaan kepentingan dan perbedaan penafsiran. BHP selaku wali pengawas yang diperintahkan oleh undang-undang memiliki kepentingan anak yang belum dewasa, apabila ada kepentingan anak yang bertentangan dengan kepentingan wali. Sedangkan lembaga lainnya memiliki penafsiran berbeda berkaitan dengan tugas dan kewenangan mereka masing-masing yang berkaitan dengan perwalian dan perlindungan harta anak adalah hubungan lembaga tersebut dengan individu/masyarakat tanpa melihat substansi dari peran wali pengawas. Perbedaan penafsiran juga terjadi mengenai pengawasan perwalian yang dianggap berlaku bagi golongan tertentu, sehingga lembaga lain tidak melibatkan wali pengawas dalam setiap perbuatan yang berkaitan dengan anak dalam perwalian;

2) Kesenjangan antara pemahaman teknis dan pemahaman hukum tentang tata pemerintahan yang baik.

Penyelenggaraan pemerintahan terkait perwalian yang masih berkutat pada sektor masing-masing lembaga. Belum diterapkannya prinsip Whole of Government ${ }^{64}$ dalam penyelenggaraan pemerintahan yang diharapkan menyatukan upaya kolaboratif pemerintahan dari seluruh sektor dalam ruang lingkup koordinasi yang lebih luas guna mencapai tujuan kepentingan yang terbaik bagi anak, khususnya terlindunginya harta kekayaan anak pada saat anak dianggap belum cakap melakukan perbuatan hukum.

3) Kendala hukum yang dihadapi dalam penerapan peraturan perundangundangan yang terdiri atas mekanisme pengaturan, administrasi pengaturan, antisipasi terhadap perubahan dan penegakan hukum;

Ketentuan mengenai Perwalian dalam KUHPerdata tidak dapat diterapkan karena lembaga lainnya belum memahami peran wali pengawas. Di samping itu, tidak lengkapnya pengaturan tentang wali pengawas.

Berkaitan dengan kondisi yang terjadi, harmonisasi hukum dapat diawali dengan melakukan penyelarasan dan penyerasian tujuan, strategi dan pedoman dari masing-masing peraturan perundang-undangan melalui upaya

64 Yogi Sufwarno dan Tri Atmojo Sejati. (2017). Whole of Government, Jakarta: Lembaga Adiministrasi Negara, hal. 1 
hukum penafsiran hukum, konstruksi hukum, penalaran hukum dan pemberian argumentasi yang rasional dengan tetap memperhatikan sistem sistem hukum dan asas hukum yang berlaku. ${ }^{65}$ Untuk menanggulangi terjadinya disharmoni dalam perwalian tersebut dapat dilakukan dengan proses negosiasi atau musyawarah, baik dengan maupun tanpa juru penengah, untuk menyelesaikan disharmoni hukum publik yang tidak bersifat pidana, seperti tumpang tindih kewenangan dan berturan kepentingan antar instansi pemerintah. ${ }^{66}$

Penyelarasan dan penyerasian akan dilakukan dengan penafsiran hukum dan konstruksi hukum dengan pendekatan harmonisasi hukum yang mengacu pada peraturan perundang-undangan dan keterpaduan kelembagaan. Melalui pendekatan perundang-undangan perlu dilakukan pengharmonisasian antara peraturan perundang-undangan yang satu dengan lainnya yang membahas mengenai perlindungan anak. Konstruksi hukum diperlukan dalam melibatkan peran wali pengawas dan perlindungan anak dalam perwalian baik mengenai harta pribadi anak maupun harta kekayaan anak. Substansi pengawasan oleh negara yang dilakukan oleh BHP dimasukkan dalam peraturan perundang-undangan guna mengawasi, memberikan pertimbangan dan persetujuan atas perbuatan hukum yang dilakukan oleh wali. Upaya yang dapat dilakukan antara lain:

1. Pengaturan sanksi bagi wali

Ketentuan dalam Pasal 368 KUHperdata, yang mewajibkan wali memberitahukan adanya perwalian pada BHP dan Pasal 372 KUHPerdata yang mengharuskan wali pengawas meminta kepada wali memberikan secara ringkas perhitungan tanggungjawab wali, bukanlah kaidah hukum yang bersifat fakultatif melainkan imperatif. Di mana ketentuan tersebut bersifat $a$ priori harus ditaati, bersifat mengikat atau memaksa. ${ }^{67}$ Apabila ketentuan tersebut tidak ditaati maka terdapat ancaman berupa sanksi bagi yang melanggarnya. Bab XI mengenai sanksi yang diatur dalam Pasal 49 Racangan Undang-Undang BHP diharapkan menjadi solusi untuk mempertegas sanksi bagi wali yang tidak menjalankan kewajibannya. Adanya sanksi pidana (penggelapan) untuk seorang wali yang tidak bersedia melaksanakan pendaftaran/pencatatan harta kekayaan anak dibawah umur setelah terjadinya perwalian. ${ }^{68}$

2. Pengaturan mengenai akibat hukum dari perbuatan hukum wali yang dilakukan tanpa sepengetahuan atau izin wali pengawas

Peraturan perundang-undangan dan dokumen hukum lainnya diharapkan dirumuskan secara jelas dan efektif. Yang dimaksud jelas di sini adalah pesan yang disampaikan dalam peraturan perundang-undangan dapat dipahami secara mudah sesuai dengan maksud pembentukannya oleh setiap orang

$65 \mathrm{Ibid}$, hal. 9-10.

${ }^{66}$ Kusnu Goesniadhie S, Op., Cit., hal. 11.

${ }^{67}$ Sudikno Mertokusumo. (2008). Mengenal Hukum Suatu Pengantar. Yogyakarta: Liberty, hal. 32

${ }^{68}$ Amri Marjunin, Perwalian dan Pengampuan dan Segala Permasalahan yang ada Serta Penyelesaiannya, dalam Patimah Sari, Op., Cit., hal. 70. 
yang akan menggunakannya atau terikat oleh peraturan perundangundangan tersebut. ${ }^{69}$ Jika diinterpretasikan secara gramatikal dan sistematis, ketentuan dalam Pasal 418 KUHPerdata ini ditujukan untuk membatasi perbuatan hukum yang dilakukan oleh wali harus melibatkan peran wali pengawas. Apabila terdapat perbuatan hukum wali atas harta kekayaan si anak, seperti jual beli, sewa menyewa, menerima/menolak waris dan hibah, melakukan pemisahan atau penggabungan harta akan memiliki akibat hukum batal demi hukum apabila tidak mendapat izin dari wali pengawas. Yang dimaksud batal demi hukum ini memiliki arti bahwa perbuatan yang dilakukan wali dianggap tidak pernah terjadi. Sedangkan yang dimaksud dengan efektif adalah ketentuan yang dirumuskan dalam peraturan perundang-undangan dapat mempengaruhi atau mengarahkan tindakan orang untuk siapa peraturan perundang-undangan ditujukan agar sesuai dengan ketentuan peraturan perundang-undangan lainnya. ${ }^{70} \mathrm{Di}$ sisi lain terdapat peraturan perundang-undangan yang mengatur persyaratan berkaitan dengan peralihan hak. Manakala persyaratan tersebut telah dipenuhi oleh wali maka perbuatan hukum tersebut dianggap telah terjadi dan syah oleh pejabat terkait. Oleh karena itu, perihal akibat hukum harus dilakukan perumusan kembali agar norma yang ada dapat diefektifkan.

3. Pengaturan Surat Keterangan/Persetujuan Wali Pengawas dalam persyaratan pengurusan di PPAT dan/atau BPN berkaitan dengan harta anak dibawah umur

Berkaitan dengan harta anak dalam perwalian berupa barang tidak bergerak yang dalam hal ini tanah, pada dasarnya peralihan hak atas tanah melalui jaul beli, tukar menukar, hibah pemasukan dan perbuatan hukum pemindahan hak lainnya dapat didaftarkan pada BPN dengan dibuktikan dengan akta oleh PPAT yang berwenang menurut ketentuan peraturan perundang-undangan yang berlaku. ${ }^{71}$ Konteks terkait anak yang memiliki hak waris dari orang tuanya yang telah meninggal tidak dapat melakukan perbuatan peralihan hak karena belum cakap sehingga orangtua yang hidup terlama harus menjadi wali berdasarkan penetapan pengadilan. ${ }^{72}$ Dalam hal perwalian yang memberikan perlindungan terhadap anak dan harta kekayaan anak, wali harus pula terlebih dahulu meminta izin dan melakukan perbuatan hukumnya di hadapan wali pengawas. PPAT memiliki suatu kewajiban untuk mempertimbangan terkait kebenaran formiil dan materiil dari perbuatan yang akan dituangkan dalam akta. Pasal 39 ayat (1) huruf e dan g PP Pendaftaran Tanah, memberikan peluang melibatkan peran wali pengawas melalui surat keterangan sebagai bentuk izin dan persyaratan lain yang harus dipenuhi oleh pemohon. Oleh karena itu perlu mengkonstruksikan aturan hukum mengenai peralihan hak atas tanah melalui jaul beli, tukar menukar, hibah pemasukan

\footnotetext{
69 A.A. Oka Mahendra. (2017). Pedoman Praktis Legal Drafting. Malang: Setara Press, hal. 122

70 Ibid.

${ }^{71}$ Indonesia, Peraturan Pemerintah Republik Indonesia Nomor 24 Tahun 1997 tentang Pendaftaran Tanah, Lembaran Negara RI 1997 Nomor 59, Pasal 37 ayat (1)

72 Elita Savira, dkk., Loc., cit.
} 
dan perbuatan hukum pemindahan hak lainnya yang berkaitan dengan harta kekayaan anak, yang tidak hanya mensyaratkan penetapan pengadilan tetapi juga menyertakan surat keterangan dari wali pengawas.

Harmonisasi hukum tidak hanya menyangkut hal-hal yang bersifat yang dimaksudkan untuk menghindari pengaturan yang tumpang tindih atau saling bertentangan tetapi juga mengenai fungsinya dengan baik dalam masyarakat. ${ }^{73}$ Oleh karena itu diperlukan keterpaduan antar lembaga yang dalam hal ini BHP sebagai wali pengawas, Pengadilan Negeri, Dinas Kependudukan dan Catatan Sipil, Notaris \& PPAT serta BPN dalam mengutamakan kepentingan terbaik bagi anak. Aspek hukum dan kelembagaan dalam tata pemerintahan yang baik diwujudkan dalam bentuk interaksi hukum dan kelembagaan. Untuk itu diperlukan konsep Whole of Government untuk dapat mensinergikan tugas dan kewenangan yang saling berhubungan tanpa menghilangkan peran dari salah satu lembaga. Harmonisasi keterpaduan kelembagaan ini dapat dimulai dengan melakukan koordinasi dengan lembaga lain. Untuk itu upaya yang perlu dilakukan antara lain:

1. Pengadilan Negeri

Keterpaduan kelembagaan antara Pengadilan Negeri dan BHP, dilakukan dalam melaksankan ketentuan yang telah diamanatkan oleh peraturan perundang-undangan, antara lain:

a. Berkaitan dengan tugas BHP yang menunggu adanya permohonan atau penetapan dari Pengadilan Negeri, dalam hal terjadinya perwalian berdasarkan Pasal 368 KUHPerdata, wali diwajibkan memberitahukan adanya perwalian kepada BHP, apabila wali lalai maka wali dapat dipecat. Namun karena adanya keterbatasan dari masyarakat yang tidak mengetahui kewajiban tersebut maka tidak dilaksanakan. Untuk itulah dibutuhkan peran Pengadilan Negeri untuk dapat mencantumkan pada amar putusan agar wali setelah penetapan memberitahukan kepada BHP. Selain wali, Pengadilan Negeri melalui panitera harus segera memberitahukan dengan surat tentang adanya pengangkatan berdasarkan Pasal 369 KUHPerdata. Oleh karena itu diperlukan sinergitas dari Pengadilan Negeri agar mencantumkan pada amarnya dan mengirimkan salinan penetapan kepada BHP, sehingga BHP segera dapat melakukan pemanggilan wali untuk menghadap.

b. Mengenai pemecatan wali yang dianggap lalai dan tidak menjalankan kewajibannya, BHP dapat meminta hakim untuk melakukan pemecatan wali tersebut. Untuk itu diperlukan sinergitas antara BHP sebagai wali pengawas dengan Pengadilan Negeri.

c. Mengenai larangan wali terhadap harta kekayaan anak pada Pasal 393 KUHPerdata, untuk meminjam uang, menggadaikan barang-barang tak bergerak, menjual atau memindahtangankan surat-surat negara harus mendapat izin dari Pengadilan, di mana pemberian izin tersebut haruslah mendengar dan memanggil dengan sah keluarga dan wali pengawas. Oleh

\footnotetext{
73 Ibid, hal. 13.
} 
karena itu diperlukan sinergitas antara Pengadilan dan BHP dalam hal mempertimbangkan alasan dari sang wali.

2. Dinas Kependudukan dan Catatan Sipil

Keterpaduan kelembagaan antara Dinas Kependudukan dan Catatan Sipil dan BHP, dilakukan dalam melaksankan ketentuan dalam Pasal 360 KUHPerdata untuk memberitahukan kepada BHP, peristiwa kematian yang meninggalkan ahli waris dibawah umur sehingga segera mungkin wali pengawas dapat menjalankan perannya untuk melakukan pengawasan terhadap anak tersebut.

3. Notaris/PPAT dan BPN

Keterpaduan kelembagaan antara Notaris dan BHP, dilakukan dalam hal perwalian terjadi atas dasar surat wasiat, Notaris melaporkannya perwalian tersebut kepada BHP. Termasuk dalam hal pemisahan dan pembagian harta yang di dalamnya terdapat harta kekayaan anak di bawah umur, maka notaris harus memberitahukan kepada BHP pembagian tersebut, sebagai diatur dalam Pasal 406 KUHPerdata.

Sedangkan hubungan BHP dengan PPAT dan BPN, berkaitan dengan perbuatan hukum yang dilakukan wali mengenai harta kekayaan anak berupa barang tidak bergerak berupa tanah. yang mana berdasarkan ketentuan Pasal 418 KUHPerdata, BHP tidak dapat dikesampingkan terhadap segala perbuatan hukum yang dilakukan oleh wali dalam mewakili si anak.

Selain diperlukan harmonisasi peraturan perundang-undangan dan harmonisasi keterpaduan kelembagaan, diperlukan juga kesadaran hukum dari wali. Kesadaran hukum ini berakaitan dengan pandangan dalam masyarakat tentang apa itu hukum dan fungsinya. ${ }^{74}$ Baik wali yang merupakan orang tua yang hidup terlama maupun seseorang yang ditunjuk melalui penetapan pengadilan diharapkan memiliki itikad baik untuk tetap mengutamakan kepentingan terbaik bagi anak dan dapat bekerjasama dengan wali pengawas. Hal tersebut dapat dimulai dengan melaksanakan ketentuan dalam Pasal 368 KUHPerdata dengan memberitahukan adanya perwalian kepada BHP, kemudian melaksanakan pengambilan sumpah, melakukan inventarisasi harta kekayaan anak, melibatkan BHP dalam setiap perbuatan hukum dan membuat laporan pertanggungjawaban berkaitan dengan adanya perwalian.

\section{Penutup}

Wali dalam menjalankan tugasnya diwajibkan untuk memelihara anak yang berada di bawah perwaliannya dan juga mengurus harta benda anak. Dalam melaksanakan perwalian tersebut, wali diawasi oleh wali pengawas, yang oleh undang-undang kewenangan tersebut diberikan pada BHP. BHP dalam hal ini melaksanakan tugas pengawasan apabila ada kepentingan anak yang bertentangan dengan kepentingan si wali. Namun, peran wali pengawas tersebut tidak dapat dilaksanakan karena disharmoni peran satu lembaga

${ }_{74}$ Sudikno Mertokusumo, Op., Cit., hal. 120. 
dengan lembaga lainnya. Hal tersebut disebabkan faktor perbedaan kepentingan dan perbedaan penafsiran, kesenjangan antara pemahaman teknis dan pemahaman hukum tentang tata pemerintahan yang baik, serta kendala hukum yang dihadapi dalam penerapan peraturan perundangundangan yang terdiri atas mekanisme pengaturan, administrasi pengaturan, antisipasi terhadap perubahan dan penegakan hukum.

Untuk menyelesaikan kondisi tersebut, perlu dilakukan penyelarasan dan penyerasian dengan cara penafsiran hukum dan konstruksi hukum dengan pendekatan harmonisasi hukum yang mengacu pada peraturan perundang-undangan dan keterpaduan kelembagaan. Melalui pendekatan perundang-undangan perlu dilakukan pengharmonisasian antara peraturan perundang-undangan yang satu dengan lainnya yang membahas mengenai perlindungan anak. Konstruksi hukum diperlukan dalam melibatkan peran wali pengawas dan perlindungan anak dalam perwalian baik mengenai harta pribadi anak maupun harta kekayaan anak. Substansi pengawasan oleh negara yang dilakukan oleh BHP dimasukkan dalam peraturan perundangundangan guna mengawasi, memberikan pertimbangan dan persetujuan atas perbuatan hukum yang dilakukan oleh wali. Kemudian, melalui harmonisasi keterpaduan kelembagaan peran BHP sebagai wali pengawas dengan lembaga/ pejabat terkait seperti Pengadilan Negeri, Dinas Kependudukan dan Catatan Sipil, Notaris \& PPAT serta BPN dalam mengutamakan kepentingan terbaik bagi anak. Pemerintah perlu melakukan konsultasi publik intensif dengan para stakeholders, transformasi hukum atau kelembagaan, Focus Group Discussion dan sosialisasi kepada masyarakat.

\section{Daftar Pustaka}

Buku

Darmabrata, Wahyono \& Surini Ahlan Sjarif. 2004. Hukum Perkawinan dan Keluarga di Indonesia. Jakarta: Fakultas Hukum Universitas Indonesia.

Departemen Kehakiman Republik Indonesia, Direktorat Jenderal Hukum dan Perundang-Undangan. Himpunan Peraturan Perundang-Undangan Balai Harta Peninggalan (Buku I).

Goesniadhie, Kusnu. 2006. Harmonisasi Hukum dalam Perspektif Perundang-undangan, Lex Spesialis Suatu Masalah. Surabaya: JPBooks. Kusnu. 2010. Harmonisasi Sistem Hukum Mewujudkan Tata Pemerintahan yang Baik. Malang: Nasa Media.

Gultom, Maidin. 2013. Perlindungan Hukum Terhadap Anak dalam Sistem Peradilan Pidana Anak di Indonesia. Bandung: Refika Aditama.

Harsono, Budi. 2008. Hukum Agraria Indonesia: Sejarah Pembentukan

Undang-Undang Pokok Agraria, Isi dan Pelaksanaannya. Jakarta:

Djambatan.

Hasan, Djuhaendah.1998. Hukum Keluarga. Bandung: Armico. 
Indrati, Maria Farida. 2007. Ilmu Perundang-Undangan 1: Jenis, Fungsi dan Materi Muatan. Yogyakarta: Kanisius.

Mahendra, A.A. Oka. 2017. Pedoman Praktis Legal Drafting. Malang: Setara Press

Marzuki, Peter Mahmud. 2005. Penelitian Hukum (Edisi Revisi). Jakarta: Kencana.

Mertokusumo, Sudikno. 2008. Mengenal Hukum Suatu Pengantar. Yogyakarta: Liberty. Sudikno. 2010. Hukum Acara Perdata Indonesia. Yogyakarta: Universitas Atma Jaya.

Prawidohamidjojo, R. Soetojo \& Marthalena Pohan. 2008. Hukum Orang dan Keluarga (Personen en Familie-Recht). Surabaya: Airlangga University Press

Subekti. 2003. Pokok-pokok Hukum Perdata. Jakarta: Intermasa.

Sufwarno, Yogi \&Tri Atmojo Sejati. 2017. Whole of Government. Jakarta: Lembaga Adiministrasi Negara.

Susanti \& Efendi. 2014. Penelitian Hukum: Legal Research. Jakarta: Sinar Grafika.

Sutedi, Adrian. 2007. Peralihan Hak Atas Tanah dan Pendaftarannya. Jakarta: Sinar Grafika.

Tanya, Bernard L. 2011. Penegakan Hukum dalam Terang Etika. Yogyakarta: Genta.

Tuti, Titik Triwulan. 2008. Hukum Perdata dalam Sistem Hukum Nasional. Jakarta: Kencana Prenadmedia Group.

Journal articles:

Abubakar, Al Yasa'. 2011. "Perlindungan Harta Anak dalam Peraturan Perundang-Undangan dan Praktek di Mahkamah Syar'iyah“. Jurnal Ilmiah Islam Futura. Vol. 10, No. 2. 1-19.

Heriyani, Endang dan Prihati Yuniarlin. 2015. “Fungsi BHP sebagai Wali Pengawas Terhadao Anak di Bawah Perwalian dalam Rangka Perlindungan anak". Jurnal Media Hukum. Vol. 22, No. 2. 218 - 231.

Idami, Zahratul. 2012. "Tanggungjawab Wali Terhadap Anak yang Berada di Bawah Perwaliannya (Suatu Penelitian di Kota Banda Aceh)". Jurnal Dinamika Hukum. Vol 12, No. 1. 60-73.

Levla, Fanny. 2017. “Tanggung Gugat Notaris dalam Pelaksanaan Pendaftaran Wasiat secara Online". Jurnal Arena Hukum. Vol. 10, No. 1. 141-162.

Putranto, Nurhendro. 2013. “Balai Harta Peninggalan Fungsi dan Tugas Pokoknya (Edisi Revisi)".

Savira, Elita, dkk. "Penetapan Perwalian Anak yang diminta PPAT sebagai Syarat Pembuatan Akta Jual Belu Hak Atas Tanah". Artikel. Program Studi Magister Kenotariatan Pascasarjana, Fakultas Hukum Universitas Brawijaya. 
Simatupang, Taufik H. 2018. “Eksistensi dan Efektivitas Pelaksanaan Tugas Balai Harta Peninggalan di Indonesia". Jurnal Penelitian Hukum De Jure. Vol. 18, No. 3. 397- 414.

Skripsi/Tesis/Disertasi:

Harca, Yudhi Marza. 2013. “Tinjauan Yuridis Pelaksanaan Perwalian Terhadap Anak dibawah umur Korban Tsunami di Aceh". Tesis. Fakultas Hukum Universitas Sumatera Utara.

Ramahdhany, Siti Hafsah. 2004. “Tanggungjawab Balai Harta Peninggalan Selaku Wali Pengawas Terhadap Harta Anak di Bawah Umur (Studi Mengenai Eksistensi Balai Harta Peninggalan Medan Sebagai Wali Pengawas)". Tesis. Universitas Sumatera Utara.

Sari, Patimah. 2017. "Peranan Balai Harta Peninggalan dalam Perwalian Berdasarkan Sistem Hukum Perdata Indonesia (Studi Balai Harta Peninggalan Medan)". Skripsi. Fakultas Hukum Universitas Sumatera Utara.

Veronita, Septy. 2013. “Hak Perwalian Anak di Bawah Umur yang Beralih pada Neneknya (Analisis kasus Putusan Mahkamah Agung Republik Indonesia Nomor:372K/Pdt/2008)". Tesis. Universitas Indonesia.

Peraturan Perundang-undangan:

Indonesia, Kitab Undang-Undang Hukum Perdata.

Indonesia, Undang-Undang Nomor 1 Tahun 1974 tentang Perkawinan, Lembaran Negara Republik Indonesia Tahun 1974 Nomor 1.

Indonesia, Kompilasi Hukum Islam

Indonesia, Undang-Undang Nomor 23 Tahun 2002 tentang Perlindungan Anak, (Lembaran Negara RI Tahun 2002 Nomor 109).

Indonesia, Undang-Undang Nomor 23 Tahun 2006 tentang Administrasi Kependudukan (Lembaran Negara RI Tahun 2006 Nomor 124, Tambahan Lembaran Negara Nomor 4674).

Indonesia, Undang-Undang Nomor 48 Tahun 2007 tentang Penetapan Peraturan Pemerintah Pengganti Undang-Undang Nomor 2 Tahun 2007 tentang Penanganan Permasalahan Hukum dalam Rangka Pelaksanaan Rehabilitasi dan Rekonstruksi Wilayah dan Kehidupan Masyarakat di Provinsi Nanggroe Aceh Darussalam dan Kepulauan Nias Provinsi Sumatera Utara menjadi Undang-Undang (Lembaran Negara RI Tahun 2007 Nomor 168, Tambahan Lembaran Negara Nomor 4796).

Indonesia, Undang-Undang Nomor 2 Tahun 2014 tentang Perubahan atas Undang-Undang Nomor 30 Tahun 2004 tentang Jabatan Notaris, Lembaran Negara RI Tahun 2014 Nomor 3, Tambahan Lembaran Negara Nomor 5491)

Indonesia, Peraturan Pemerintah Republik Indonesia Nomor 24 Tahun 1997 tentang Pendaftaran Tanah, (Lembaran Negara RI Tahun 1997 Nomor 59).

Indonesia, Keputusan Menteri Kehakiman RI Nomor M.01.PR.07.01-80 Tahun 1980 tentang Organisasi dan Tata Kerja Balai Harta Peninggalan. 
Website:

Sistem Informasi Penelusuran Perkara Pengadilan Negeri Surabaya. http://sipp.pn-

surabayakota.go.id/list_perkara/page/1/SXYwTGR3b3VMc2FISi9Ce HV0YXZjblBSdTdraG1LRFV6d3hBdFZtbWw5MjRwYkNva0M2bzIrR21 YdDREUDVDQTJLcDVZR3JUNUwxZDIMeHBUdDI5M1E9PQ==/WG 5LZDh1SE5IS0VuVHFER3o2dzd2REsrU1V4WTJNb3R2TC9BVGg3cW NwM3ISNj1CcUtxbStGTHgzMURwQk8xZ1g3NTB5MlVPSkk1YldOc0h $\underline{\mathrm{kYko5Q} 2 \mathrm{c} 9 \mathrm{PQ}==/ \mathrm{col} / 2}$. diakses pada 10 Februari 2019. 